\title{
Effect of water regimes and plant densities on cowpea production ${ }^{1}$
}

\author{
Marinete Martins de Sousa Monteiro ${ }^{2}$, Edson Alves Bastos ${ }^{3}$, \\ Milton José Cardoso ${ }^{3}$, Aderson Soares de Andrade Júnior ${ }^{3}$, Valdenir Queiroz Ribeiro ${ }^{3}$
}

\section{ABSTRACT}

Cowpea has been cultivated in a rudimentary form in the main producing regions of Brazil, resulting in lower grain yields, when compared to the crop potential. The use of technologies such as water regimes, adequate plant density and soil management are alternatives to increase this crop yield. This study aimed at evaluating the effects of different water regimes and plant densities on the yield components of cowpea cultivated under conventional and no-tillage systems. A randomized block design in a split-plot factorial, with four replications, was used. The treatments consisted of five water regimes in the plots $(157.00 \mathrm{~mm}, 189.00 \mathrm{~mm}, 234.00 \mathrm{~mm}$, $274.00 \mathrm{~mm}$ and $320.00 \mathrm{~mm}$ ) and five plant densities as subplots (12 plants $\mathrm{m}^{-2}, 16$ plants $\mathrm{m}^{-2}, 20$ plants $\mathrm{m}^{-2}, 24$ plants $\mathrm{m}^{-2}$ and 28 plants $\mathrm{m}^{-2}$ ). The evaluated variables were: number of pods per plant, number of pods per area, pod length and grain yield. The combination between $270 \mathrm{~mm}$ of irrigation water depth with a density of 280,000 plants ha ${ }^{-1}$ resulted in higher grain yield using the no-tillage system, while the combination between the density of 280,000 plants ha- ${ }^{-1}$ and $320 \mathrm{~mm}$ of water depth favored the highest grain yields in the conventional growing system.

KEYWORDS: Vigna unguiculata (L.) Walp.; grain yield; irrigation.

\section{INTRODUCTION}

Cowpea [Vigna unguiculata (L.) Walp] is a crop with socioeconomic importance for the Northeast and North regions of Brazil, due to its low production cost and because it is an important source of protein for the low income populations of these regions, thus generating employment and income (Freire Filho et al. 2005). Due to its expansion in planted areas and in the consumption of this legume,

\section{RESUMO}

Efeito de regimes hídricos e

densidades de plantas na produção de feijão-caupi

O feijão-caupi tem sido cultivado de forma rudimentar nas principais regiões produtoras do Brasil, ocasionando baixas produtividades de grãos, em comparação ao potencial da cultura. A utilização de tecnologias como regimes hídricos, densidade de plantas e manejo adequado do solo são alternativas para aumentar os rendimentos dessa cultura. Objetivou-se avaliar os efeitos de regimes hídricos e densidades de plantas sobre os componentes de produção e produtividade de feijão-caupi, em sistemas de cultivo convencional e direto. Utilizou-se delineamento em blocos casualizados, em parcelas subdivididas, com quatro repetições. Os tratamentos foram cinco regimes hídricos nas parcelas (157,00 mm; 189,00 mm; 234,00 mm; 274,00 mm; 320,00 mm) e cinco densidades de plantas como subparcelas (12 plantas $\mathrm{m}^{-2}$, 16 plantas $\mathrm{m}^{-2}, 20$ plantas $\mathrm{m}^{-2}, 24$ plantas $\mathrm{m}^{-2}$ e 28 plantas $\mathrm{m}^{-2}$ ). As variáveis analisadas foram: número de vagens por planta, número de vagens por área, comprimento de vagens e produtividade de grãos. A combinação entre a lâmina de irrigação de $270 \mathrm{~mm}$ e a densidade de 280.000 plantas ha $^{-1}$ promoveu maiores ganhos na produtividade de grãos no plantio direto, enquanto a combinação entre a densidade de 280.000 plantas ha $^{-1}$ e a lâmina de $320 \mathrm{~mm}$ favoreceu os melhores rendimentos da produtividade de grãos no plantio convencional.

PALAVRAS-CHAVE: Vigna unguiculata (L.) Walp.; produtividade de grãos; irrigação.

in recent years, it has become an excellent income alternative for small growers and large farmers.

However, despite being a genetically improved crop, concerning size and architecture for mechanized cultivation, its growing is still rudimentary in the main producing regions of Brazil. As a result of the low level of technology applied, the average grain yield is low, reaching the national average of 400$500 \mathrm{~kg} \mathrm{ha}^{-1}$ (Alves et al. 2009). In the Piauí state, the average yield is $256 \mathrm{~kg} \mathrm{ha}^{-1}$, lower than the crop

1. Manuscript received in Jul./2017 and accepted for publication in Dec./2017 (http://dx.doi.org/10.1590/1983-40632017v4747908).

2. Universidade Federal do Piauí, Teresina, PI, Brasil.E-mail: marinettmartins@hotmail.com.

3. Empresa Brasileira de Pesquisa Agropecuária (Embrapa Meio-Norte), Teresina, PI, Brasil. E-mails: edson.bastos@embrapa.br, milton.cardoso@embrapa.br, aderson.andrade@embrapa.br, valdenir.ribeiro@embrapa.br. 
potential estimated at $\sim 6,000 \mathrm{~kg} \mathrm{ha}^{-1}$. This low grain yield may be attributed to the water deficit and the low use of technologies, such as lack of adequate soil management, inadequate use of plant density and no irrigation management (Freire Filho et al. 2005).

Many authors (Bezerra et al. 2012 and 2014, Cardoso et al. 2015) have studied the plating density of cowpea in Brazil. Plant density significantly influences the cowpea grain yield, as it significantly alters the number of pods per plant or area, which is the main production component (Cardoso et al. 2005). In semi-prostrate growth habit cultivars, Cardoso et al. (2015) obtained quadratic responses for the number of pods per area, observing maximum values of 110.2 pods $\mathrm{m}^{-2}, 92.6$ pods $\mathrm{m}^{-2}$ and 92.9 pods $\mathrm{m}^{-2}$, respectively at the plant densities of $12.8 \mathrm{~m}^{-1}, 13.0 \mathrm{~m}^{-1}$ and $13.3 \mathrm{~m}^{-1}$ (BRS Aracê).

Thus, it is very important to define an adequate plant population, especially considering the diversity of cowpea materials and cultivation systems. Typically, for erect varieties, a higher number of plants per area $\left(180,000-220,000\right.$ plants $\left.\mathrm{ha}^{-1}\right)$ is recommended, when compared to semi-prostrate or prostrate varieties $\left(120,000-140,000\right.$ plants ha $\left.{ }^{-1}\right)$.

When the irrigation is well conducted, it increases both cowpea yield and grain quality (Oliveira et al. 2011, Silva et al. 2013 and 2016, Locatelli et al. 2014). Silva et al. (2016) evaluated 20 genotypes under irrigation and observed an average grain yield $27 \%$ higher than the same genotypes under no irrigation. These differences may be doubled or tripled in areas with severe water deficiency. The presence of straw on the soil surface during the cowpea development, combined with irrigation management, is an important tool, promoting a reduction in water evaporation (Locatelli et al. 2014). The crop residues on the soil act altering the soil-water relationship, thus reducing the transpiration rate of the crops, especially in the phases in which the soil is not covered by the crop itself, the irrigation frequency and operating costs (Stone et al. 2006).

The no-tillage system may be an advantageous alternative for a higher yield, when compared to the conventional system, because the straw on the soil surface of the no-tillage system reduces the water evaporation, thus saving water. There are few studies in the literature regarding the cowpea yield under no-tillage system and submitted to different population densities. This cropping system reduces the drastic effects of climatic conditions unfavorable to the crop development (Simidu et al. 2010), such as water deficit and thermal stress. The crop residues act as an insulating agent, preventing abrupt fluctuations in the soil temperature and contributing to the lower water evaporation from the soil, with a better use of water by plants (Bizari et al. 2009).

This study aimed at evaluating the effects of water regimes and plant densities on the yield components of cowpea cultivated under conventional and no-tillage systems.

\section{MATERIAL AND METHODS}

Two experiments were carried out in the experimental field of the Embrapa Meio-Norte, in Teresina, Piauí state, Brazil ( $5^{\circ} 05^{\prime} \mathrm{S}, 42^{\circ} 29^{\prime} \mathrm{W}$ and $74.40 \mathrm{~m}$ of altitude), from June to August 2016, using conventional and no-tillage systems. The climate of the area, according to the Thornthwaite and Mather climate classification, is C1sA'a', and, considering the historical records from 1980 to 2014 , presents an average annual temperature of $28.1{ }^{\circ} \mathrm{C}$ and average annual precipitation of 1,342.4 $\mathrm{mm}$ (Bastos \& Andrade Júnior 2015).

The soil of the experimental area is an eutrophic Yellow-Red Argisol, with a mild elevation relief and 0-3 \% of slope (Melo et al. 2014). The soil granulometric and chemical analysis are presented in Tables 1 and 2, respectively.

Two experiments were carried out under conventional and no-tillage systems. For each experiment, a randomized block design in a splitplot factorial, with four replications, was used. The treatments werefive water regimes $(50 \%, 75 \%, 100 \%$, $125 \%$ and $150 \%$ of the crop evapotranspiration, corresponding to $157 \mathrm{~mm}, 189 \mathrm{~mm}, 234 \mathrm{~mm}, 274 \mathrm{~mm}$ and $320 \mathrm{~mm}$, respectively) in the plots and five plant densities (12 plants $\mathrm{m}^{-2}, 16$ plants $\mathrm{m}^{-2}, 20$ plants $\mathrm{m}^{-2}$, 24 plants $\mathrm{m}^{-2}$ and 28 plants $\mathrm{m}^{-2}$ ) in the subplots. The experiment consisted of 100 subplots in each planting system. The plots consisted of 5 rows of $4 \mathrm{~m}$, spaced

Table 1. Granulometric analysis of the soil of the experimental area.

\begin{tabular}{ccccc}
\hline \multirow{2}{*}{$\begin{array}{c}\text { Depth } \\
(\mathrm{m})\end{array}$} & \multicolumn{4}{c}{ Granulometry $\left(\mathrm{g} \mathrm{kg}^{-1}\right)$} \\
\cline { 2 - 5 } & Coarse sand & Fine sand & Silt & Clay \\
\hline $0.0-0.2$ & 451.8 & 190.4 & 164.5 & 193.3 \\
$0.2-0.4$ & 471.3 & 180.2 & 168.0 & 178.7 \\
\hline
\end{tabular}


Table 2. Chemical analysis of the soil from the experimental area.

\begin{tabular}{|c|c|c|c|c|c|c|c|c|c|c|c|}
\hline Depth & $\mathrm{OM}$ & $\mathrm{pH}$ & P & $\mathrm{K}^{+}$ & $\mathrm{Na}^{+}$ & $\mathrm{Ca}^{2+}$ & $\mathrm{Mg}^{2+}$ & $\mathrm{Al}^{3+}$ & $\mathrm{H}^{+}+\mathrm{Al}^{3+}$ & CEC & $\mathrm{V}$ \\
\hline $\mathrm{m}$ & $\mathrm{g} \mathrm{kg}^{-1}$ & $\mathrm{H}_{2} \mathrm{O}$ & $\mathrm{mg} \mathrm{dm}^{-3}$ & & & & $\mathrm{mmol}$ & -3 & & & $\%$ \\
\hline $0.0-0.2$ & 7.7 & 6.1 & 34.4 & 0.2 & 0.04 & 2.2 & 0.5 & 0.05 & 1.4 & 4.5 & 66.8 \\
\hline $0.2-0.4$ & 8.5 & 6.0 & 25.1 & 0.2 & 0.04 & 2.1 & 0.5 & 0.05 & 1.9 & 4.9 & 60.0 \\
\hline
\end{tabular}

at $0.5 \mathrm{~m}$, totaling $10 \mathrm{~m}^{2}$. The useful area of the plot totaled $4.0 \mathrm{~m}^{2}$, being the two central rows.

The soil preparation in the conventional growing system consisted of cutting, plowing and harrowing. In the area under the no-tillage system, sorghum and brachiaria straw were used on the soil. The base fertilization was carried out according to the soil analysis and followed the crop nutritional requirements, with $50 \mathrm{~kg} \mathrm{ha}^{-1}$ of $\mathrm{P}_{2} \mathrm{O}_{5}$ and $40 \mathrm{~kg} \mathrm{ha}^{-1}$ of $\mathrm{K}_{2} \mathrm{O}$ (Melo \& Cardoso 2017). Seeding was performed on 24 June 2016, using the BRS Itaim cultivar for the two systems and $0.50 \mathrm{~m}$ between planting furrows, with the seeds at $0.03 \mathrm{~m}$ of depth.

The irrigations were carried out by a fixed conventional sprinkler system, with nozzle impact sprayers of $4.4 \mathrm{~mm} \times 3.2 \mathrm{~mm}$ and flow rate of $1.59 \mathrm{~m}^{-3} \mathrm{~h}^{-1}$, at a pressure of $3.0 \times 105 \mathrm{~Pa}$, spaced $12 \mathrm{~m} \times 12 \mathrm{~m}$. To verify the efficiency of the application of the irrigation depth in each treatment, at 6 days after sowing, 16 collectors were installed in each water regime, totalizing 80 collectors in the experimental area. The reference evapotranspiration was estimated based on the average daily climatic data of air temperature, relative air humidity, global solar radiation and wind speed obtained from an automatic meteorological station installed near the experiment. The water regime was applied restoring the crop evapotranspiration determined based on the reference evapotranspiration, estimated by the Penman-Monteith method, according to methodology proposed by Allen et al. (1998), and in the cowpea crop coefficient (Table 3 ) recommended by Andrade Júnior et al. (2000).

Table 3. Crop coefficients for cowpea according to the cycle phases used at the experimental area.

\begin{tabular}{ccc}
\hline Cycle phase & Days after seeding & Crop coefficient \\
\hline I & $0-15$ & 0.50 \\
II & $16-44$ & 0.80 \\
III & $45-57$ & 1.05 \\
IV & $58-65$ & 0.75
\end{tabular}

Up to 18 days after sowing, one daily irrigation was applied in the amount of $100 \%$ of the crop evapotranspiration from the previous day. From the eighteenth day after sowing, water regimes defined in the treatments were applied. The maximum plant density ( 28 plants $\mathrm{m}^{-2}$ ) was sown and, at 15 days after sowing, a thinning was carried out, in order to adjust the treatments proposed in this study.

Harvesting was carried out on 29 August 2016. The useful area of each plot was represented by the two central rows. From that, the following production components were obtained: number of pods per area, pod length $(\mathrm{cm})$ and dry grain yield $\left(\mathrm{kg} \mathrm{ha}^{-1}\right)$, corrected to $13 \%$ of moisture.

Analyses of variance were performed to test the significance of the irrigation water depths, plant density and the interaction between these factors. Because the interaction between the two factors was significant, multiple regression analyses were performed, following the methods proposed by Custódio et al. (2000), Pimentel-Gomes (2009) and Zimmermann (2014). A reduced model was fit, consisting of nine parameters containing the isolated linear and quadratic effects, as well as the linear and quadratic interactions, as it follows: $\mathrm{Y}=\mathrm{b} 0+\mathrm{b} 1 \mathrm{~A}+$ $\mathrm{b} 2 \mathrm{~A}^{2}+\mathrm{b} 3 \mathrm{~B}+\mathrm{b} 4 \mathrm{~B}^{2}+\mathrm{b} 5 \mathrm{AB}+\mathrm{b} 6 \mathrm{AB}^{2}+\mathrm{b} 7 \mathrm{~A}^{2} \mathrm{~B}+$ $\mathrm{b} 8 \mathrm{~A}^{2} \mathrm{~B}^{2}$, in which $\mathrm{Y}$ is the dependent variable, $\mathrm{b} 0$ the constant of regression, $\mathrm{b} 1, \ldots, \mathrm{b} 8$ the regression coefficients and A and B the independent variables, consisting of the irrigation water depths and plant densities, respectively.

The best model was selected based on the $t$ test for each parameter, accepting the significance of $15 \%$ (Conagin \& Jorge 1982). The statistical analyses were performed with the SAS software (SAS Institute 2015).

\section{RESULTS AND DISCUSSION}

Analyses of variance detected a significant effect of water regimes and plant densities for all the variables (number of pods per plant, number of pods per area, pod length and grain yield), for both 
the conventional and no-tillage systems (Tables 4 and 5 , respectively). The interaction between the factors was also significant for all the evaluated variables.

In the conventional system, the highest value was 2.3 pods per plant (corresponding to 5.3, with data transformation to $\sqrt{\mathrm{x}}$ ), with the use of $318 \mathrm{~mm}$ of water depth and density of 12-14 plants $\mathrm{m}^{-2}$ (Figure 1A). Number of pods per plant is a variable that decreases with increasing plant density (Bezerra et al. 2012), due to an intraspecific competition compromising photosynthesis.

Bezerra et al. (2014), studying plant densities under irrigated regime, verified linear decreases in the number of pods per plant with an increase in plant density. It was observed a reduction of $66.48 \%$, from 100,000 plants ha ${ }^{-1}$ to 500,000 plants $\mathrm{ha}^{-1}$, which resulted, on average, in 14.62 and 4.90 pods per plant, respectively.

From plants cultivated in the no-tillage system, the same pattern was observed for number of pods per plant, when compared to the conventional system. However, the highest value observed was 2.8 , when a density of $12-13$ plants $\mathrm{m}^{-2}$ was used with 282 of water depth (Figure 1B). This lower water depth value may be explained by the fact that the crop residues provide a higher water retention in the soil (Figure 1B). Bastos et al. (2011) evaluated the effect of water deficit on physiological and productive characteristics of cowpea, to select tolerant genotypes to water deficit, and observed that the water deficit, which was obtained by applying approximately half of the water amount required by the cowpea, reduced the average number of pods per plant by $175 \%$ and the grain yield by $60 \%$.

The results obtained in this research, both for the conventional and no-tillage systems, show that the interaction between plant density and applied water depths is significant $(\mathrm{p} \leq 0.01)$, and it can be inferred that the higher the plant density and the lower the irrigation, the lower the number of pods per plant. On the other hand, it is possible to verify that the number of pods per plant is responsive to irrigation, a result also observed by Andrade Júnior et al. (2002), although with maximum values obtained

Table 4. Variance analysis of cowpea (BRS Itaim) for the number of pods per plant, number of pods per area, pod length and grain yield, for the conventional system.

\begin{tabular}{|c|c|c|c|c|c|}
\hline \multirow{2}{*}{ Source of variation } & \multicolumn{5}{|c|}{ Mean square $^{1}$} \\
\hline & $\mathrm{DF}$ & Number of pods per plant & Number of pods per area & Pod length $(\mathrm{cm})$ & Grain yield $\left(\mathrm{kg} \mathrm{ha}^{-1}\right)$ \\
\hline Block & 3 & $0.0766^{\mathrm{ns}}$ & $1.0770^{\mathrm{ns}}$ & $0.4648^{\mathrm{ns}}$ & $93,554.020^{\mathrm{ns}}$ \\
\hline Water depth (WD) & 4 & $2.9683 * *$ & $58.9907 * *$ & $10.8009 * *$ & $2,361,409.99 * *$ \\
\hline Error (a) & 12 & 0.0628 & 0.8747 & 0.5258 & $112,063.676$ \\
\hline Density (DENS) & 4 & $1.1349 * *$ & $5.2283^{* *}$ & $3.5374 * *$ & $49,712.866 * *$ \\
\hline WD*DENS & 16 & $0.1236^{* *}$ & $1.8928 * *$ & $1.5747^{*}$ & $34,651.654 * *$ \\
\hline Error (b) & 60 & 0.0113 & 0.1591 & 0.4534 & $22,517.64$ \\
\hline CV(a) (\%) & & 15.87 & 13.63 & 4.95 & 18.94 \\
\hline $\mathrm{CV}(\mathrm{b})(\%)$ & & 6.72 & 5.82 & 4.59 & 13.88 \\
\hline
\end{tabular}

Table 5. Variance analysis of cowpea (BRS Itaim) for the number of pods per plant, number of pods per area, pod length and grain yield, for the no-tillage system.

\begin{tabular}{lrcccc}
\hline \multirow{2}{*}{ Source of variation } & \multicolumn{5}{c}{ Mean square $^{1}$} \\
\cline { 2 - 6 } & DF & Number of pods per plant & Number of pods per area & Pod length $(\mathrm{cm})$ & ${\text { Grain yield }\left(\mathrm{kg} \mathrm{ha}{ }^{-1}\right)}^{\text {nas }}$ \\
\hline Block & 3 & $0.0073^{\text {ns }}$ & $0.1119^{\text {ns }}$ & $0.5106^{\text {ns }}$ & $6,632.83^{\text {ns }}$ \\
Water depth (WD) & 4 & $2.8578^{* *}$ & $50.8047^{* *}$ & $15.3268^{* *}$ & $3,735,844.64^{* *}$ \\
Error (a) & 12 & 0.0450 & 0.9553 & 0.2995 & $78,693.29$ \\
Density (DENS) & 4 & $1.8513^{* *}$ & $3.4373^{* *}$ & $1.8223^{* *}$ & $123,835.42^{* *}$ \\
WD*DENS & 16 & $0.1122^{* *}$ & $0.8550^{* *}$ & $1.0283^{* *}$ & $53,664.31^{* *}$ \\
Error (b) & 60 & 0.0180 & 0.2946 & 0.1568 & $22,265.43$ \\
\hline $\mathrm{CV}(\mathrm{a})(\%)$ & 10.82 & 11.38 & 3.56 & 23.89 \\
\hline $\mathrm{CV}(\mathrm{b})(\%)$ & 6.84 & 6.32 & 2.58 & 12.71 \\
\hline
\end{tabular}


with different water depths, as those observed in the present study.

For the number of pods per area, it was verified that the highest value observed in the conventional growing system was 8.8 (data transformed to $\sqrt{\times}$ ), obtained in the highest plant density evaluated in this study $\left(28\right.$ plants $\left.\mathrm{m}^{-2}\right)$ and in the highest irrigation regime used (320 mm) (Figure 2A). For plants from the no-tillage system, the number of pods per area was 10.25 (transformed to $\sqrt{ } \times$ ), higher than the one observed for the conventional system. This maximum value was obtained with the same plant density and
(A)

$$
\begin{aligned}
& \mathrm{Y}=-0.5244+0.1769 * * * \mathrm{D}+0.000029 * * \mathrm{~L}^{2}- \\
& 0.0065 * * * \mathrm{D}^{2}+0.000015 * * * \mathrm{LD}^{2}-0.0000016^{* * *} \mathrm{~L}^{2} \mathrm{D}
\end{aligned}
$$

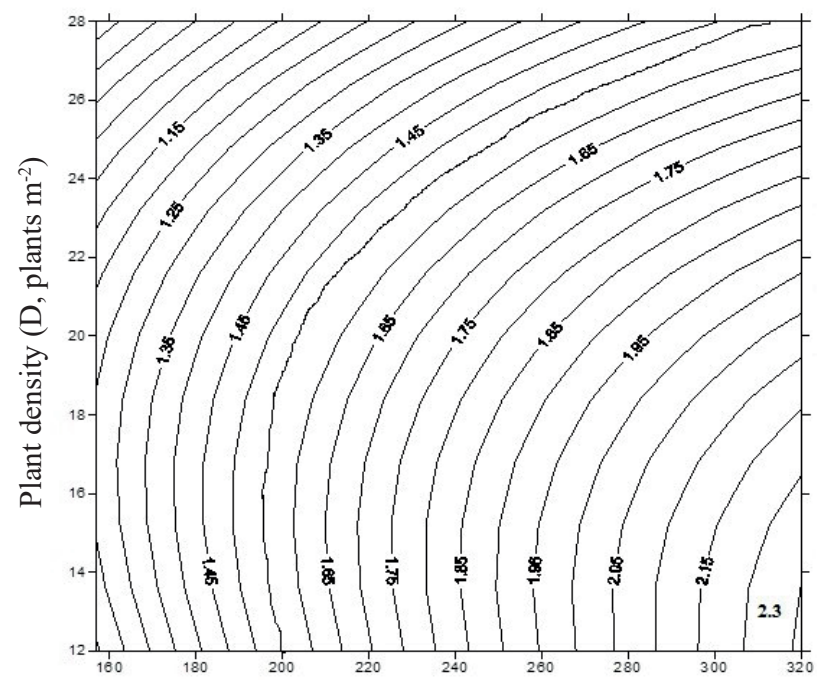

(B) $\quad \mathrm{Y}=-3.49319+0.04582 * * * \mathrm{~L}-0.000074 * * * \mathrm{~L}^{2}+$ $0.02661 * * \mathrm{D}-0.00031492 * * * \mathrm{LD}$

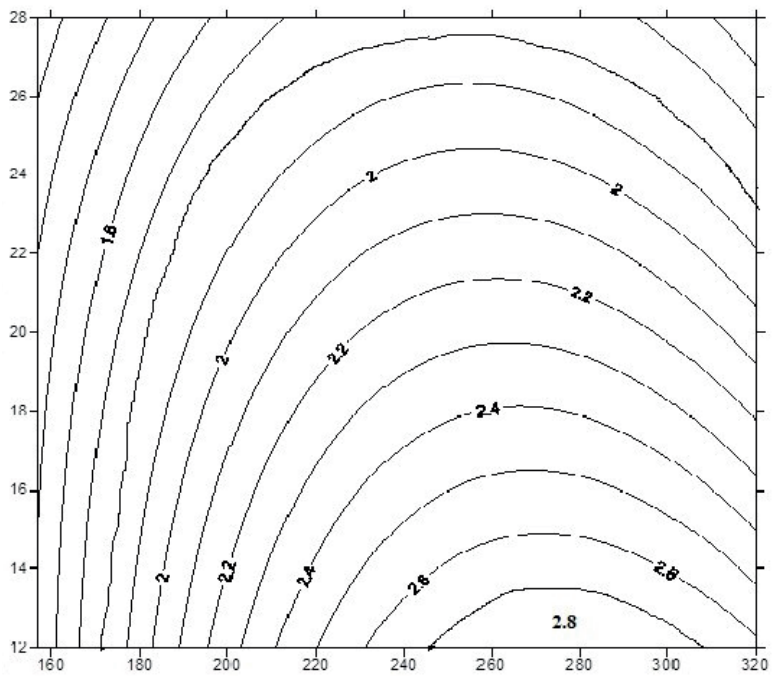

Water depth $(\mathrm{L}, \mathrm{mm})$

Figure 1. Response surfaces for the number of pods per plant (data transformed to $\sqrt{ } \times$ ) of cowpea (BRS Itaim), according to water depths and plant densities, in the conventional (A) and no-tillage (B) systems.

(A)

$\mathrm{Y}=-0.5985+0.1320 * * * \mathrm{D}+0.000056 * * * \mathrm{~L}^{2}+$ $0.0083^{* * *} \mathrm{D}^{2}+0.0025 * * * \mathrm{LD}-0.0000056^{* * *} \mathrm{~L}^{2} \mathrm{D}$

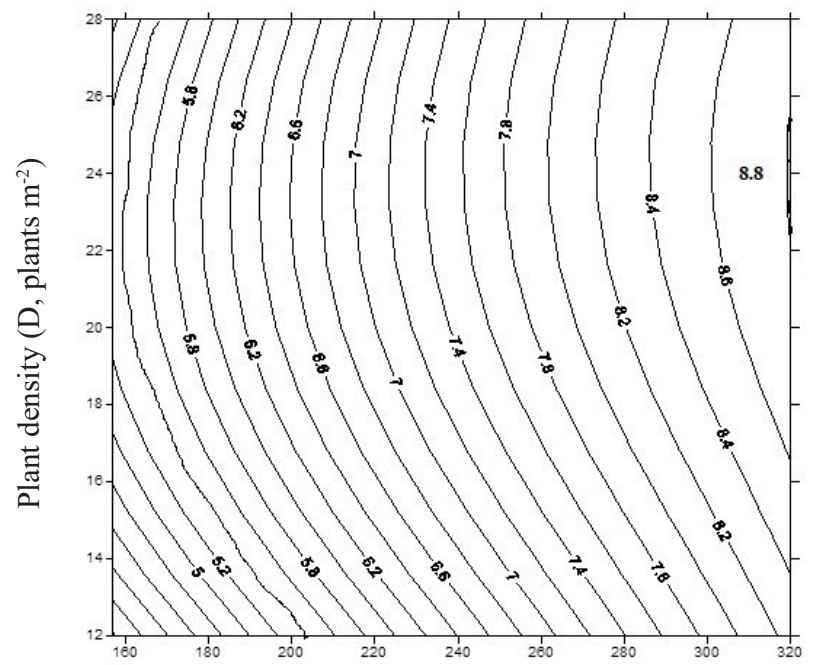

(B) $\mathrm{Y}=-13.55909+0.15682 * * * \mathrm{~L}-0.00027108 * * * \mathrm{~L}^{2}+$ $0.16650 * * * \mathrm{D}-0.00045461 * * \mathrm{LD}$

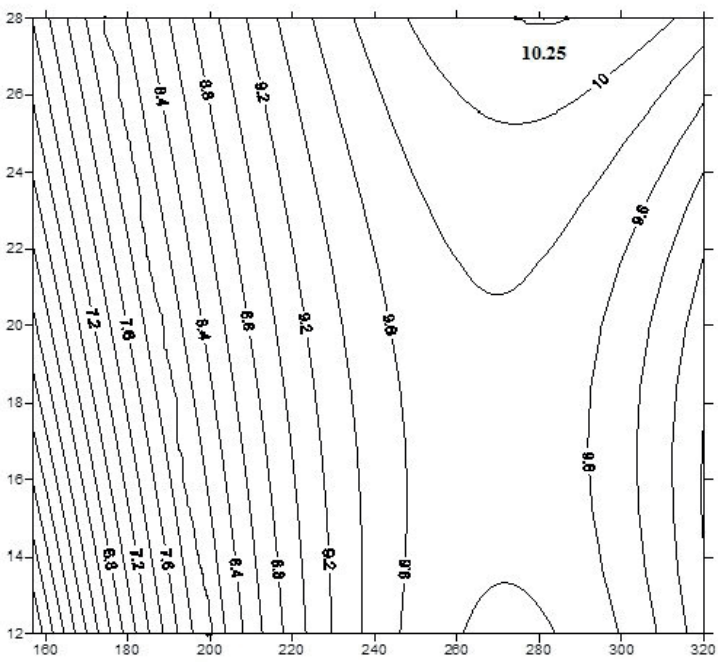

Water depth (L, mm)

Figure 2. Response surfaces for the number of pods per area (data transformed to $\sqrt{ } \times$ ) of cowpea (BRS Itaim), with the application of water regimes and plant densities, under conventional (A) and no-tillage (B) systems. 
$265 \mathrm{~mm}$ of water depth, a decrease of $17.2 \%$ in irrigation (Figure 2B).

It was observed a tendency to increase the number of pods per area with a higher number of plants per area $\left(280,000\right.$ plants $\left.\mathrm{ha}^{-1}\right)$ for both production systems. Although the greatest number of plants per area resulted in a reduction in the photoassimilates production (intraspecific competition), there is a compensatory effect due to the higher number of plants per area. This result corroborates Shimada et al. (2000), who observed that the grain yield was favored by increasing the plant density.

The highest value for pod length in the conventional system was $15.74 \mathrm{~cm}$, obtained with $312 \mathrm{~mm}$ of water depth and density of 17 plants $\mathrm{m}^{-2}$, according to the response surface (Figure 3A). The results showed a significant quadratic effect for irrigation regimes and plant density for this variable under the conventional and no-tillage systems. Superior results were observed by Silva et al. (2013), evaluating the cowpea under irrigated regime, with $17.7 \mathrm{~cm}$ of pod length for the BRS Itaim cultivar.

In the no-tillage system, the highest pod length was $16.34 \mathrm{~cm}$, when a density of 21 plants $\mathrm{m}^{-2}$ was used with $285 \mathrm{~mm}$ of water depth, which is lower, when compared to the one used in the conventional growing system. Silva et al. (2016) evaluated the dry grain yield and cowpea production components under an irrigated system and observed increases in the pod length values $(16-22 \mathrm{~cm})$ with higher water depths $(360 \mathrm{~mm})$ than the ones tested in this study. Freitas et al. (2013) observed that the no-tillage and conventional systems may influence the following cowpea production components: pod length, number of grains per pod, number of grains per plant and grain yield.

The highest value for grain yield in the conventional system was $1,166.36 \mathrm{~kg} \mathrm{ha}^{-1}$, with a $320 \mathrm{~mm}$ depth and density of 28 plants $\mathrm{m}^{-2}$ (Figure 4A). The results indicate that there is a combination of irrigation depth and plant density that provides higher values for cowpea grain yield in this system. It is possible that the conventional growing system, by allowing a higher water evaporation from the soil, requires a higher water depth when irrigated. The density of 28 plants $\mathrm{m}^{-2}$ resulted in the highest number of pods per plant and, consequently, a higher grain yield.

Oliveira et al. (2015), evaluating the interaction between water depths and plant densities in the cowpea growth and yield, using a conventional production system, observed a grain yield of $1,668.86 \mathrm{~kg} \mathrm{ha}^{-1}$, using $390.88 \mathrm{~mm}$ of water depth and density of 24.1 plants $\mathrm{m}^{-2}$, for the BRS Itaim cultivar. Souza et al. (2011) evaluated cowpea under a conventional production system and observed a grain yield of $1,376.9 \mathrm{~kg} \mathrm{ha}^{-1}$, with $449 \mathrm{~mm}$ of

\section{(A) \\ $\mathrm{Y}=1.7844+0.0594 * * * \mathrm{~L}+0.5341 * * * \mathrm{D}-0.000080 * \mathrm{~L}^{2}-$ $0.0104 * * * \mathrm{D}^{2}-0.00055 * * \mathrm{LD}$}

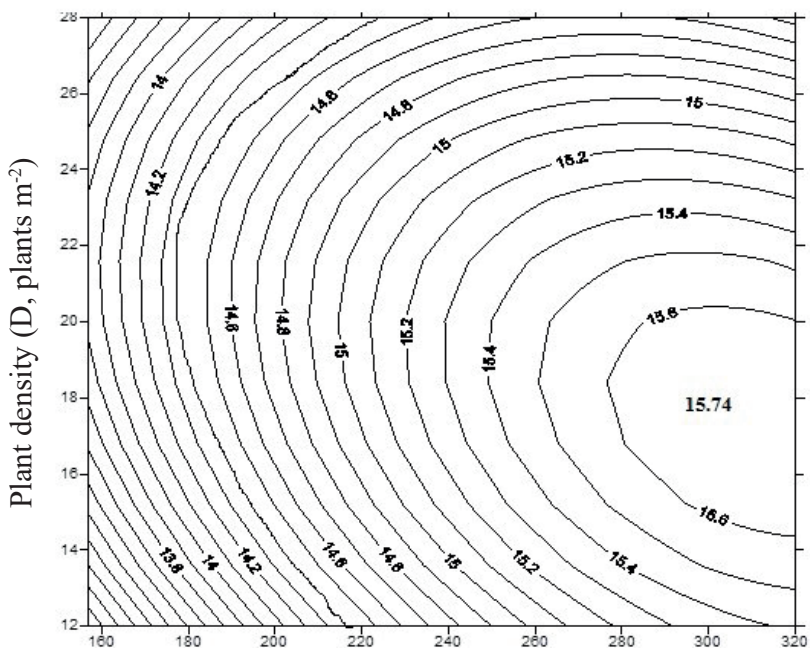

(B)
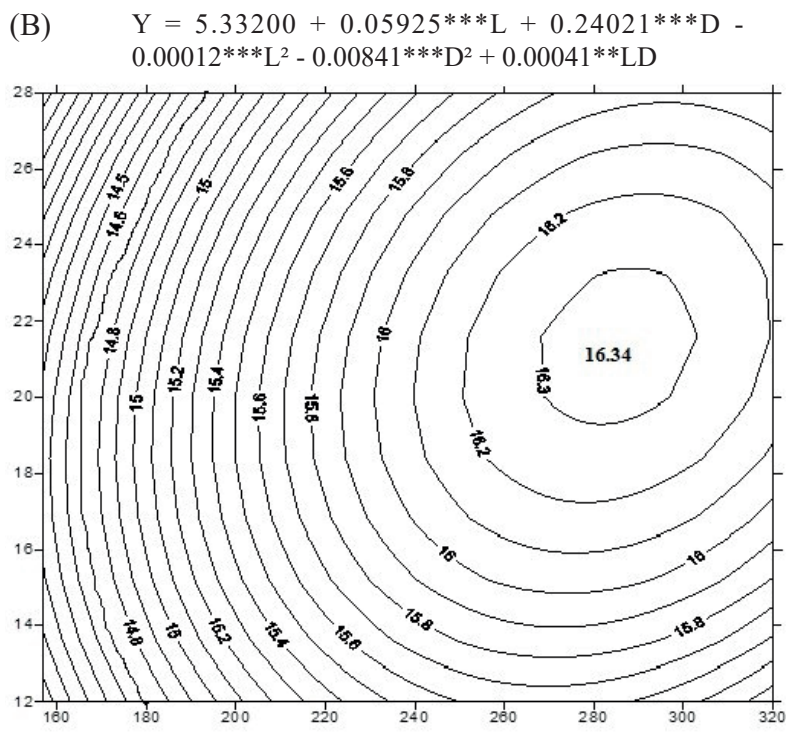

Water depth (L, mm)

Figure 3. Response surfaces for the cowpea (BRS Itaim) pod length, with the application of water regimes and plant densities, under conventional (A) and no-tillage (B) systems. 
(A)

$$
\begin{aligned}
& \mathrm{Y}=-1065.7490+131.2384 * * * \mathrm{D}+0.0216 * \mathrm{~L}^{2}- \\
& 4.7086 * * \mathrm{D}^{2}+0.0142 * * * \mathrm{LD}^{2}-0.0012 * * * \mathrm{~L}^{2} \mathrm{D}
\end{aligned}
$$

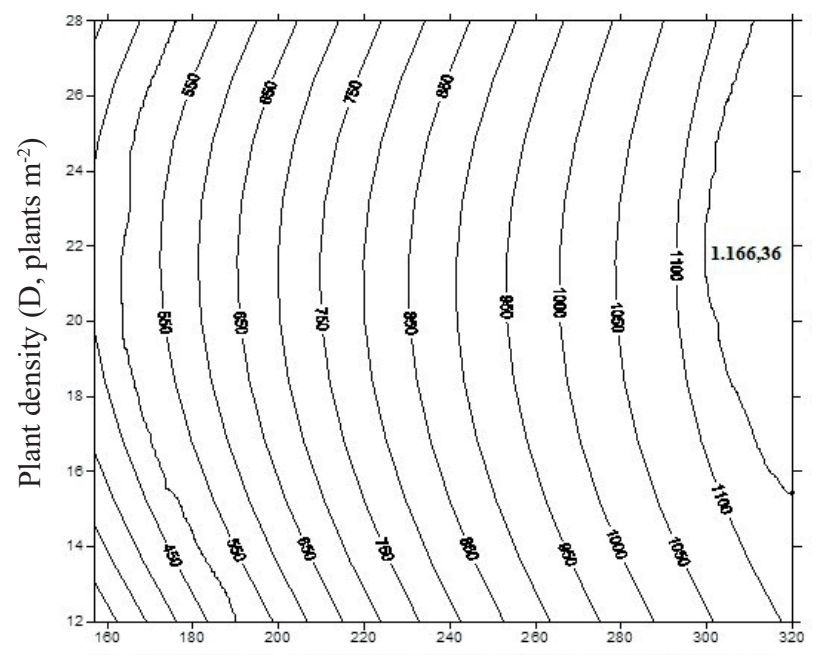

(B) $\mathrm{Y}=-354.79423+0.02077 ! \mathrm{L}^{2}-143.96085 * * * \mathrm{D}+2.05238 * * * \mathrm{LD}-$ $0.00536 * * * \mathrm{~L}^{2} \mathrm{D}-0.01664 ! \mathrm{LD}^{2}+0.00006015 ! \mathrm{L}^{2} \mathrm{D}^{2}$

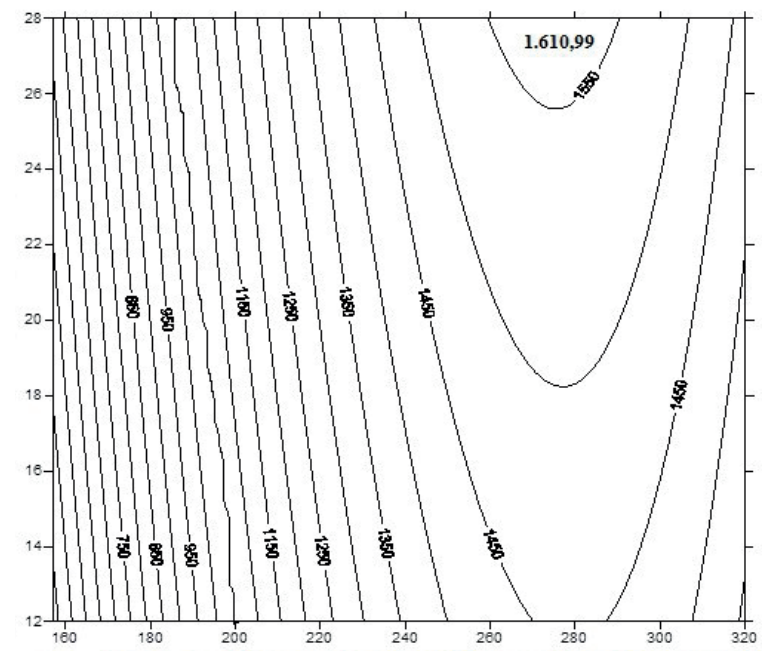

Water depth (L, mm)

Figure 4. Response surfaces for grain yield $\left(\mathrm{kg} \mathrm{ha}^{-1}\right)$ of cowpea (BRS Itaim), with the application of water regimes and plant densities, under conventional (A) and no-tillage (B) systems.

water depth, being $29 \%$ higher than the one used in this study.

Silva et al. (2016), evaluating the dry grain yield and cowpea production, observed increases of $30.4 \%$, with values ranging $886.72-1,274.06 \mathrm{~kg} \mathrm{ha}^{-1}$, with irrigation of $360 \mathrm{~mm}$ depth, under the conventional production system.

In the no-tillage system, the highest yield obtained was $1,610.99 \mathrm{~kg} \mathrm{ha}^{-1}$, when the density of 28 plants $\mathrm{m}^{-2}$ and irrigation with $270 \mathrm{~mm}$ of water depth were applied (Figure 4B). The results indicate that the increase in irrigation promoted an increase in grain yield, up to the maximum limit of $270 \mathrm{~mm}$. The Urochloa (syn. Brachiaria) and sorghum crop residues used in the no-tillage system favored the reduction of water losses by evaporation. This resulted in a greater water efficiency in this system, so that the production component number of pods per area was the most influenced one, requiring a smaller water volume to reach a higher grain yield.

Tagliaferre et al. (2013) observed higher values for these variables in a study with cowpea (Guariba cultivar), according to water depths, and noticed a quadratic behavior reaching the maximum grain yield of $2,820.03 \mathrm{~kg} \mathrm{ha}^{-1}$, with $462 \mathrm{~mm}$ of water depth. These results are corroborated by Locatelli et al. (2014), who evaluated cowpea in a Yellow Latosol, under a no-tillage system, and observed an influence of the irrigation depth in the dry grain yield.

\section{CONCLUSIONS}

1. Irrigation with $270 \mathrm{~mm}$ of water depth, associated with a density of 280,000 plants $\mathrm{ha}^{-1}$, resulted in a higher grain yield, under the no-tillage growing system;

2. The density of 280,000 plants ha-1 and $320 \mathrm{~mm}$ of water depth favored the best grain yields, when the conventional growing system was used.

\section{ACKNOWLEDGMENTS}

To the Embrapa Meio-Norte, for the technical and logistic support (experimental field), and Coordenação de Aperfeiçoamento de Pessoal de Nível Superior (Capes), for the $\mathrm{PhD}$ scholarship granted to the first author.

\section{REFERENCES}

ALLEN, R. G.; PEREIRA, L. S.; RAES, D.; SMITH, M. Crop evapotranspiration: guidelines for computing crop water requirements. Rome: FAO, 1998.

ALVES, J. M. A. et al. Avaliação agroeconômica da produção de cultivares de feijão-caupi em consórcio com cultivares de mandioca em Roraima. Revista Agro@mbiente,v.3, n. 1, p. 15-30, 2009.

ANDRADE JÚNIOR, A. S. et al. A cultura do feijão caupi no meio-norte do Brasil. Teresina: Embrapa Meio-Norte, 2000. (Circular técnica, 28). 
ANDRADE JÚNIOR, A. S. et al. Níveis de irrigação na cultura do feijão-caupi. Revista Brasileira de Engenharia Agrícola e Ambiental, v. 6, n. 1, p. 17-20, 2002.

BASTOS, E. A. et al. Identification of cowpea genotypes for drought tolerance. Revista Ciência Agronômica, v. 42, n. 1, p. 100-107, 2011.

BASTOS, E. A.; ANDRADE JUNIOR, A. S. Boletim agrometeorológico de 2015 para o município de Teresina, Piauí. Teresina: Embrapa Meio-Norte, 2015. (Documentos, 239).

BEZERRA, A. A. C. et al. Comportamento morfoagronômico de feijão-caupi, cv. BRS Guariba, sob diferentes densidades de plantas. Revista Ciências Agrárias, v. 55, n. 3, p. 184-189, 2012.

BEZERRA, A. A. de C. et al. Morfofisiologia e produção de feijão-caupi, cultivar BRS Nova Era, em função da densidade de plantas. Revista Caatinga, v. 27, n. 4, p. 135141, 2014.

BIZARI, D. R. et al. Consumo de água e produção de grãos do feijoeiro irrigado em sistemas plantio direto e convencional. Ciência Rural, v. 39, n. 7, p. 2073-2079, 2009.

CARDOSO, J. M. et al. Densidades de plantas de feijãocaupi de porte semiprostrado sob irrigação. Teresina: Embrapa Meio-Norte, 2015. (Documentos, 110).

CARDOSO, J. M. et al. Ecofisiologia e manejo de plantio. In: FREIRE FILHO, F. R.; LIMA, J. A. A.; RIBEIRO, V. Q. Feijão-caupi: avanços tecnológicos. Teresina: Embrapa, 2005. p. 213-225.

CONAGIN, A.; JORGE, J. P. N. de. Delineamento (1/5) (5 x 5 x 5) em blocos. Bragantia, v. 41, n. 16, p. 155-168, 1982.

CUSTÓDIO, T. N. et al. Superfície de resposta em experimento com parcelas subdivididas. Ciência \& Agrotecnologia, v. 24, n. 4, p. 1008-1023, 2000.

FREIRE FILHO, F. R. et al. Melhoramento genético. In: FREIRE FILHO, F. R.; LIMA, J. A. de A.; RIBEIRO, V. Q. (Eds.). Feijão-caupi: avanços tecnológicos. Brasília, DF: Embrapa Informação Tecnológica, 2005. p. 28-92.

FREITAS, R. M. O. de et al. Produção de feijão-caupi sob efeito de veranico nos sistemas de plantio direto e convencional. Semina: Ciências Agrárias, v. 34, n. 6, p. 3683-3690, 2013.

LOCATELLI, V. da E. R. et al. Componentes de produção, produtividade e eficiência da irrigação do feijão-caupi no Cerrado de Roraima. Revista Brasileira de Engenharia Agricola e Ambiental, v. 18, n. 6, p. 574-580, 2014.
MELO, F. B. ; CARDOSO, J. C. Solos e adubação. In: BASTOS, E. A. Cultivo de feijão-caupi. 2. ed. Brasília, DF: Embrapa Meio-Norte, 2017.

MELO, F. B. et al. Levantamento, zoneamento e mapeamento pedológico detalhado da área experimental da Embrapa Meio-Norte em Teresina, PI. Teresina: Embrapa Meio-Norte, 2014. (Documentos, 231).

OLIVEIRA, G. A. et al. Resposta do feijão-caupi às lâminas de irrigação e às doses de fósforo no Cerrado de Roraima. Revista Ciência Agronômica, v. 42, n. 4, p. 872-882, 2011.

OLIVEIRA, S. R. M. de et al. Interação de níveis de água e densidade de plantas no crescimento e produtividade do feijão-caupi, em Teresina, PI. Irriga, v. 20, n. 3, p. 502513, 2015.

PIMENTEL-GOMES, F. Curso de estatística experimental. 15. ed. Piracicaba: ESALQ, 2009.

SAS INSTITUTE. SAS/STAT 14.1 user's guide. Cary: SAS Institute, 2015.

SHIMADA, M.; SÁ, M. E.; ARF, O. Componentes do rendimento e desenvolvimento do feijoeiro comum de porte ereto sob diferentes densidades populacionais. Bragantia, v. 59, n. 2, p. 181-187, 2000.

SILVA, E. F. et al. Avaliação de cultivares de feijão-caupi irrigado para produção de grãos verdes em Serra Talhada PE. Revista Caatinga, v. 26, n. 1, p. 21-26, 2013.

SILVA, G. C. et al. Rendimento de grãos secos e componentes de produção de genótipos de feijão-caupi em cultivo irrigado e de sequeiro.RevistaAgro@mbiente, v. 10, n. 4, p. 342-350, 2016.

SIMIDU, H. M. et al. Efeito do adubo verde e época de semeadura sobre a produtividade do feijão, em plantio direto em região de Cerrado. Acta Scientiarum Agronomy, v. 32, n. 2, p. 309-315, 2010.

SOUZA, L. S. B. et al. Eficiência do uso da água das culturas do milho e do feijão-caupi sob sistemas de plantio exclusivo e consorciado no Semiárido brasileiro. Bragantia, v. 70, n. 3, p. 715-721, 2011.

STONE, L. F. et al. Evapotranspiração do feijoeiro irrigado em plantio direto sobre diferentes palhadas de culturas de cobertura. Pesquisa Agropecuária Brasileira, v. 41, n. 4, p. 577-582, 2006.

TAGLIAFERRE, C. et al. Características agronômicas do feijão-caupi inoculado em função de lâminas de irrigação e de níveis de nitrogênio. Revista Ceres, v. 60, n. 2, p. 242 248, 2013.

ZIMMERMANN, F. J. P. Estatística aplicada à pesquisa agrícola. 2. ed. Santo Antônio de Goiás: Embrapa Arroz e Feijão, 2014. 